\title{
Shape Controlled Synthesis of Barium Carbonate Microclusters and Nanocrystallites using Natural Polysachharide - Gum Acacia
}

\author{
B. Sreedhar ${ }^{1, *}$, Ch. Satya Vani ${ }^{2}$, D. Keerthi Devi ${ }^{1}$, M. V. Basaveswara Rao ${ }^{3}$, C. Rambabu ${ }^{2}$ \\ ${ }^{1}$ Inorganic and Physical Chemistry Division, Indian Institute of Chemical Technology (Council of Scientific and Industrial Research), \\ Hyderabad 500607 Andhra Pradesh, India \\ ${ }^{2}$ Department of Chemistry, Acharya Nagarjuna University P.G. Centre, Nuzividu-521201, Andhra Pradesh, India \\ ${ }^{3}$ Department of Chemistry, Krishna University, Machilipatnam-521001,Andhra Pradesh, India
}

\begin{abstract}
Different morphosynthesis strategies for $\mathrm{BaCO}_{3}$ using natural polysaccharide-gum acacia (GA) as templating species are presented. The influence of GA with different functionalities such as $-\mathrm{OH},-\mathrm{COOH}$ and $-\mathrm{NH}_{2}$ on the crystallization and structure formation was investigated. Some interesting morphologies, including rods, dumbbell, double-dumbbell and flower like clusters, can be readily generated by using GA as cooperative modifier in the mineralization process, under the conditions of $0.5 \%, 1 \%$ of templating species and at ambient temperature. The modifier GA and its concentration is the key factor in this system. In continuation, morphology was also examined for mixed metal carbonates $\left(\mathrm{Ba}-\mathrm{LaCO}_{3}\right.$, $\mathrm{Ba}-\mathrm{TbCO}_{3}$ ). The possible formation mechanism of the nanocrystallites is discussed. Structural characterization of the synthesized materials was investigated by Powder X-ray diffraction (XRD), Scanning Electron Microscopy (SEM), Energy Dispersive Analysis (EDAX), Transmission Electron Microscopy (TEM), Thermogravimetric analysis (TGA) coupled Mass (MS) and Fourier Transform Infrared spectroscopy (FT-IR).
\end{abstract}

Keywords Biomaterials, Composite Materials, Crystal Growth, Electron Microscopy

\section{Introduction}

The study of mineral formation in biological systems, biomineralization, provides inspiration for novel approaches to the synthesis of new materials. Biomineralization relies on extensive organic-inorganic interactions to induce and control the synthesis of inorganic materials. In recent years, bioinspired morphosynthesis of crystals with hierarchical forms in the presence of organic templates having complex functionalizing patterns have been explored widely so as to mimic natural biominerals[1-6]. Among a variety of construction methodologies of functional materials, patterned crystal arrays of organic[7], inorganic[8,9] and their hybrid crystals[10,11], have received considerable attention in recent years for their diverse application potential in areas such as catalysis, medicine, pigments, cosmetics, separation technology[12,13], nano-devices[14] and find diverse applications in nanotechnology[15,16].

Nanostructural materials have become attractive because of their unique characteristics that can hardly be obtained from conventional bulk materials owing to their quantum

* Corresponding author:

sreedharb@iict.res.in (B. Sreedhar)

Published online at http://journal.sapub.org/materials

Copyright (C) 2012 Scientific \& Academic Publishing. All Rights Reserved size and surface effects. So, there has been considerable interest in fabrication of low-dimensional nanosized materials such as nanowires, nanorods and nanotubes. Several processes have been explored in the literature for the synthesis of nanomaterials. These processes involve both physical and chemical methods[17-20]. Various artificial complexations have been investigated as models of biomineralization using modifier agents, e.g., urease[21], nitrilo triacetic acid, citric acid[22], poly(acrylic acid) (PAA)[23], poly(methacrylic acid) PMMA, poly(ethylene glycol) PEG [24], poly(allylamine hydrochloride) PAH, poly (sodium 4-styrene sulfonate) PSS[25], (cetyl trimethyl ammonium bromide) $\mathrm{CTAB}[26]$. These modifying agents have also been thought to control the polymorph of the barium carbonate clusters. However, the characterization of these native and modifier agents on the crystal surface is still unclear.

$\mathrm{BaCO}_{3}$ has attracted a lot of recent research[27-30] due to its close relationship with aragonite, a prevalent and important biomineral, with many important applications in the ceramic and glass industries as well as its use as a precursor for magnetic ferrites and/or ferroelectric materials[31]. Barium carbonate $\left(\mathrm{BaCO}_{3}\right)$ is also used as a precursor for producing superconductor and ceramic materials[32] and other important applications in optical glass and electric condensers[33]. Therefore, in the present study, we report 
the synthesis and characterization of $\mathrm{BaCO}_{3}$ nanocrystallite using natural polymer, gum acacia.

Polymer-mediated mineralization of inorganic materials has been the subject of intense research because polymers have been found to dramatically influence the characteristics of an inorganic precipitate. The ability to influence the morphology and phase of an inorganic precipitate has important technological implications[34], because some physical properties of crystalline materials such as the brilliance of color pigments or the dielectric function of electroceramics depend on crystal habit, grain size, grain size distribution, impurities, or content of polymorphous modifications. Control of nucleation, crystal growth, and organization of crystals to a superstructure ("texture") make these physical properties tunable and are thus important for technical application[35].

The present investigation deals with the influence of Gum Acacia a natural polysaccaharide as templating species for the formation of $\mathrm{BaCO}_{3}$ nanocrystallites self- assembling into microclusters.

Gum Acacia is a natural gum made of hardened sap derived from Acacia Senegal and Acacia Seyel. GA consists of mainly three fractions (1) The major one is a highly branched polysaccharide consisting of $\beta-(1-3)$ galactose backbone with linked branches of D-galactose (38\%), L-arabinose (45\%), L-rhamnose (4\%), which terminate in D-glucuronic acid (7\%), and 4-O-methyl-D-glucuronic acid (6\%). (2) A smaller fraction ( $\sim 10 \mathrm{wt} \%$ of the total) arabinogalactan-protein complex (GAGP-GA glycoprotein) in which arabinogalactan chains is covalently linked to a protein chain through serine and hydroxyproline groups. The attached arabinogalactan in the complex contains $\sim 13 \%$ (by mole) glucoronic acid. (3) The smallest fraction $(\sim 1 \%$ of the total) having the highest protein content $(\sim 50 \mathrm{wt} \%)$ is a glycoprotein which differs in its amino acids composition from that of the GAGP complex. Here the functional groups namely, hydroxyl (-OH) present in arabinose and rhamnose and carboxylic $(-\mathrm{COOH})$ in glucoronic acid play a crucial role in the growth and formation of metal carbonates whereas the proteinaceous core in amino acids stabilizes the formed metal carbonates[36]. It not only acts as a stabilizer [37], but also acts as surfactant and templating agent for which the functional group moieties $\left(-\mathrm{OH}, \mathrm{COOH} \&-\mathrm{NH}_{2}\right)$ have been found to play a key role in mimicking the biomineralization process. The crystallization involves the formation of different hierarchical structures like rods through dumbbell to flower shaped which have never been seen before in natural biominerals. Proteins and polysaccharides with complicated patterns of various functional groups in GA selectively adsorb on to the metal ion thereby hindering the crystal growth, followed by the mesoscale self-assembly of nanometer-scale building block into hierarchial superstructures[38-42]. The key reaction of $\mathrm{CO}_{2}$ with $\mathrm{Ba}^{2+}$ ions entrapped within GA polymer leads to the growth of beautiful structures of witherite nanocrystalline, such an aggregated morphology not normally observed using other surfaces as templates. This templating species composed of many anionic moieties, which interacts strongly with ions, crystal surfaces. Functional, watersoluble polymers with the ability to bind ions and crystals play a major role as scale inhibitors crystal faces and thus, promotes the crystal growth. This species also strongly modify the morphology of growing crystals in an interesting manner. Indeed, in the presence of such templating species, the nucleated crystals may adopt a variety of shapes. The interacting part of the $\mathrm{GA}\left(-\mathrm{OH}, \mathrm{COOH} \&-\mathrm{NH}_{2}\right)$ can be selected or designed in such a way that it specifically adsorbs to a certain crystal face. The proteins and inorganic ions regulate the phase of the deposited mineral[43,44].

The aim of the study was to determine the effects of GA on the morphological and structural characteristics of the resulting different morphological structures, with special emphasis on different phases in the growth process. Our results demonstrate that by varying the reaction conditions the interaction of gum acacia (GA) with the precursors, results in controlling the shape, size, and microclusters of the inorganic crystals by means of a simple mineralization process.

\section{Experimental}

\subsection{Materials}

Analytical grade chemicals of $\mathrm{BaCl}_{2}, \mathrm{LaCl}_{2}, \mathrm{TbCl}_{2}$, gum acacia, sodium bicarbonate were purchased from Merck, India and used as such without further purification. Double distilled water was used in all experiments.

\subsection{Preparation of $\mathrm{BaCO}_{3}$ Microclusters}

In a typical procedure, at room temperature, $0.2442 \mathrm{~g}$ $(1 \mathrm{mM})$ of $\mathrm{BaCl}_{2}$ was taken along with different proportions of homogenized GA $(0.5 \%$ and $1.0 \%)$ in different $25 \mathrm{ml}$ glass beakers. They were dissolved in $20 \mathrm{ml}$ distilled water and the mixed solution was blended thoroughly with the help of magnetic stirrer. Then $\mathrm{NaHCO}_{3}(2 \mathrm{mM} ; 2 \mathrm{ml})$ solution is added by vigorous stirring and the reaction mixture was kept for $24 \mathrm{~h}$ crystallization at room temperature. After $24 \mathrm{~h}$, the crystals are filtered and washed several times with distilled water and dried at room temperature.

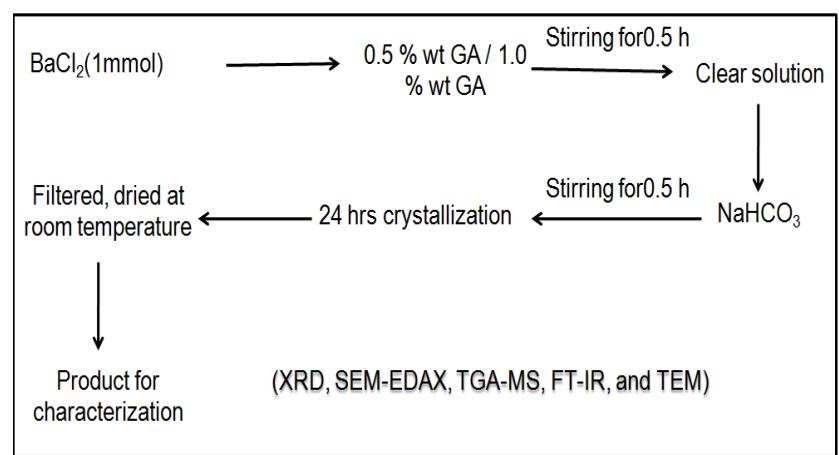

Figure 1. Flow chart for the synthesis of microclusters of $\mathrm{BaCO}_{3}$ using gum acacia

Control experiment was also carried out in aqueous solu- 
tion without the addition of GA. As prepared $\mathrm{BaCO}_{3}$ microclusters using $1 \% \mathrm{GA}$ were calcined at $700^{\circ} \mathrm{C}$. Similarly in case of mixed metal carbonates, $0.2442 \mathrm{~g}(1 \mathrm{mM})$ of $\mathrm{BaCl}_{2}$ and $0.1083 \mathrm{~g}(0.25 \mathrm{mM})$ of $\mathrm{LaCl}_{2}$ or $0.0933 \mathrm{~g}(0.25 \mathrm{mM})$ of $\mathrm{TbCl}_{2}$ were used. Hydrothermal reactions were carried out in parallel using Teflon lined autoclaves with internal volume of $10 \mathrm{ml}$ at temperatures 60 and $90^{\circ} \mathrm{C}$ for both the concentrations of GA $(0.5 \%$ and $1.0 \%)$ under autogenous pressure. After $24 \mathrm{~h}$ reaction time the autoclaves were allowed to cool to $50^{\circ} \mathrm{C}$ and maintained at that temperature for about $15 \mathrm{~h}$ before being allowed to cool slowly to ambient temperature over 3 to $4 \mathrm{~h}$. The sizes and morphologies of the products were examined by XRD, SEM-EDAX, TGA-MS, TEM, and FT-IR. Figure 1 shows the flow chart for the synthesis of microclusters of $\mathrm{BaCO}_{3}$ using gum acacia.

\subsection{Characterization Methods}

X-ray diffraction measurements of barium carbonate clusters were recorded using a Rigaku diffractometer $(\mathrm{Cu} \mathrm{Ka}$ radiation, $\lambda=0.1546 \mathrm{~nm}$ ) running at $40 \mathrm{kV}$ and $40 \mathrm{~mA}$ (Tokyo, Japan). FT-IR spectra of $\mathrm{BaCO} 3$ structures were recorded with a Thermo Nicolet Nexus (Washington, USA) 670 spectrophotometer. TEM images were observed on TECNAI FE12 TEM instrument operating at $120 \mathrm{kV}$ using SIS imaging software. The particles were dispersed in methanol and a drop of it was placed on Formvar-coated copper grid followed by air drying. Scanning electron microscopy (FEI Quanta 200 FEG with EDS) was used for morphology assessment of $\mathrm{BaCO} 3$ crystals. The crystals were collected on a round cover glass $(1.2 \mathrm{~cm})$, washed with deionized water and dried in a desiccator at room temperature. The cover glass was then mounted on a SEM stub and coated with gold for SEM analysis. Thermogravimetric Analysis (TGA) coupled to Balzer Mass (MS) was carried out on a TGA/SDTA Mettler Toledo 851e system using open alumina crucibles containing samples weighing about 8-10 $\mathrm{mg}$ with a linear heating rate of $10^{\circ} \mathrm{C}$ min- 1 . Nitrogen was used as purge gas for all these measurements.

\section{Results and Discussion}

\subsection{Structural Characterization of $\mathrm{BaCO}_{3}$ Microclusters}

The phase structures of the obtained samples were characterized by X-ray powder diffraction (XRD). Figure 2 shows the X-ray diffraction patterns of $\mathrm{BaCO}_{3}$ synthesized without GA, with GA (1\%) at room temperature, hydrothermal treatment at $90^{\circ} \mathrm{C}$ and calcined product at $700^{\circ} \mathrm{C}$. The XRD pattern of $\mathrm{BaCO}_{3}$ crystals obtained are pure orthorhombic $\mathrm{BaCO}_{3}$ crystals. All the observed peaks can be perfectly indexed to a pure orthorhombic witherite phase and no characteristic peaks from other impurities have been detected in the synthesized products. The observed diffraction peaks $\left(2 \theta\left[{ }^{\circ}\right]\right)$ : can be correlated to the (hkl) indices (110), (020), (111), (021), (002), (012), (112), (200), (220), (040), (221), (041), (202), (132), (113) and (222) respec- tively, of pure orthorhombic witherite (JCPDS card number: 85-0720). It may also be seen that the peak (111) is the strongest in all the $\mathrm{BaCO}_{3}$ crystals synthesized using various routes, suggesting that $\mathrm{BaCO}_{3}$ crystals are well oriented and grew mainly along the (111) face. The extra diffraction peaks (102) and (130) observed in the calcined product is due to increase in crystallinty. Along with (111) face several other strong diffraction peaks in the XRD pattern suggest that the crystallinity of $\mathrm{BaCO}_{3}$ nanocrystallites obtained is excellent, and can be correlated to TEM (SAED) micrograph. The diffraction spots can be indexed on the orthorhombic phase and those results are in good agreement with the results of $\mathrm{XRD}$. It can be concluded that GA has major influence on the growth and size morphology of $\mathrm{BaCO}_{3}$ crystals formed. However, the addition of templating species has no effect on the internal crystal structure of the resulting $\mathrm{BaCO}_{3}$ crystals as no changes are observed in the XRD patterns.

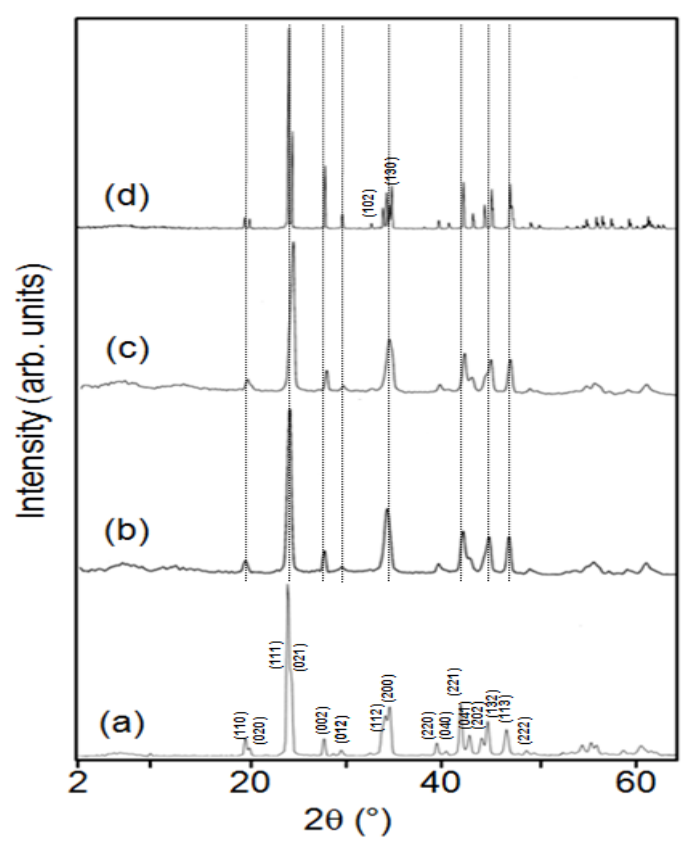

Figure 2. XRD pattern of $\mathrm{BaCO}_{3}$ crystals (a) absence of $\mathrm{GA}$, (b) presence of GA (1\%), (c) hydrothermal at $90^{\circ} \mathrm{C}(1 \%)$, and (d) calcined at $700^{\circ} \mathrm{C}(1 \%)$.

\subsection{Effect of Gum Acacia on the Morphology of $\mathrm{BaCO}_{3}$}

The morphology of the obtained $\mathrm{BaCO}_{3}$ crystals was remarkably influenced by the synthetic protocol used such as hydrothermal treatment and varying concentration of GA. Morphologies of the formed crystal aggregates were investigated using SEM-EDAX and TEM. Under ambient conditions in the absence of any templating species only rod-shaped crystals of witherite in the form aragonite-type crystals (Figure 3a) with different sizes (700 nm to $20 \mu \mathrm{m}$ length, $200 \mathrm{~nm}$ to $2 \mu \mathrm{m}$ diameter) were formed as expected. Significant changes have been observed in the morphology of the products obtained in the presence of the templating species - GA. Bunch of rods, dumbbell, double-dumbbell and flower shaped $\mathrm{BaCO}_{3}$ clusters were observed for $0.5 \%$ and $1.0 \%$ GA concentration depending on the reaction conditions. These clusters are of sizes in several nanometers 
to several micrometers at both ambient (Figure 3b, c) and hydrothermal crystallization conditions (Figure 3d, e). SEM images of the products formed after $24 \mathrm{~h}$ of reaction at various concentrations of GA $(0.5 \%$ and $1.0 \%)$ in both the reaction conditions are shown in figure 3.

At room temperature, when GA concentration was $0.5 \%$, bunch of rods in the form of clusters are seen as shown in figure $3 \mathrm{~b}$. The length of the rods present in the clusters is in the size range from $100 \mathrm{~nm}$ to $400 \mathrm{~nm}$. The enlarged image clearly shows that the rods aggregate in the form of bunch like clusters (Figure 4a). When the amount of GA added is increased to $1.0 \%$, shorter assemblies of $\mathrm{BaCO}_{3}$ aggregates in the form of dumbbell, double dumbbell and flower like clusters are observed, as depicted in figure $3 \mathrm{c}$. These clusters constitute nanosized subunits with size around $30 \mathrm{~nm}$. The enlarged SEM images of both the concentrations are separately shown in figure $4 \mathrm{~b}$. Similar morphological changes were observed in both the concentrations except variation in the size of the cluster and alignment of rods. With the increase in concentration of GA the size of the cluster increased but the nanocrystallite size decreased. This behavior can be attributed due to the effective passivation of the surfaces and suppression of the growth of the nanoparticles through strong interactions with the particles via there functional molecular groups of acacia namely, hydroxyl groups of arabinose, rhamnose and galactose and carboxylic groups of glucoronic acid moieties. Progressive changes in the assembled $\mathrm{BaCO}_{3}$ clusters indicated that the arrangement continued to grow principally in width rather than in length when the crystals interlinked. Although the individual rods observed in the absence of templating species are often disordered, they were structurally intact, suggesting that there are strong interparticle interactions between adjacent rods. Significantly, the HR-SEM images show that the $\mathrm{BaCO}_{3}$ crystals appear to be higher-order superstructures, exhibiting close morphological alignment of the rod shaped crystals into microclusters. Further, crystal growth of $\mathrm{BaCO}_{3}$ was monitored under hydrothermal crystallization at $60^{\circ} \mathrm{C}$ and $90^{\circ} \mathrm{C}$. Since there is no much variation in the morphology observed, the results obtained at $90^{\circ} \mathrm{C}$ are shown in figure $3 \mathrm{~d}$, e. At $90^{\circ} \mathrm{C}$ stacks of rods are arranged randomly and appear like flowers at lower gum acacia concentration $(0.5 \%)$, whereas at higher concentration $(1 \%)$, more number of flower like clusters are seen but there is no change in the morphology as observed in figure $3 \mathrm{~d}$, e. From this it is evident that during hydrothermal crystallization, at two different concentrations common morphology i.e.; flower shaped clusters are seen except their number increased at higher ratio of metal/ligand concentration, and the size of the clusters is also almost similar. This attributes that increasing concentration does not have much effect on the crystal morphology during hydrothermal crystallization. Moreover, temperature variation also does not have any impact in the growth morphology except variation in size. On the other hand, synthesis of $\mathrm{BaCO}_{3}$ nanostructures at ambient condition show influence of concentration on the morphology and arrangement of the clusters formed. The schematic illustra- tion of $\mathrm{BaCO}_{3}$ crystal morphology is shown in the table 1 .

Table 1. Morphology of $\mathrm{BaCO}_{3}$ at different concentrations of gum acacia

\begin{tabular}{|c|c|c|c|}
\hline \multirow{2}{*}{$\begin{array}{c}\text { Condi- } \\
\text { tion }\end{array}$} & \multicolumn{3}{|c|}{ Morphology of $\mathrm{BaCO}_{3}$} \\
\cline { 2 - 4 } Ambient & $\begin{array}{c}\text { witherite in the form } \\
\text { of rods (arago- } \\
\text { nite-type crystals) }\end{array}$ & $\begin{array}{c}\text { Bunch of rods in } \\
\text { the form of } \\
\text { cluster }\end{array}$ & $\begin{array}{c}\text { Dumbbell, double } \\
\text { dumbbell and flower } \\
\text { shaped clusters }\end{array}$ \\
\hline $\begin{array}{c}\text { Hydro- } \\
\text { thermal } \\
\left(60^{\circ}\right)\end{array}$ & $\begin{array}{c}\text { witherite in the form } \\
\text { of rods (arago- } \\
\text { nite-type crystals) }\end{array}$ & $\begin{array}{c}\text { Flower like } \\
\text { clusters (less } \\
\text { number) }\end{array}$ & $\begin{array}{c}\text { Flower like clusters } \\
\text { (more number) }\end{array}$ \\
\hline $\begin{array}{c}\text { Hydro- } \\
\text { thermal } \\
\left(90^{\circ}\right)\end{array}$ & $\begin{array}{c}\text { witherite in the form } \\
\text { of rods (arago- } \\
\text { nite-type crystals) }\end{array}$ & $\begin{array}{c}\text { Flower like } \\
\text { clusters (less } \\
\text { number) }\end{array}$ & $\begin{array}{c}\text { Flower like clusters } \\
\text { (more number) }\end{array}$ \\
\hline
\end{tabular}

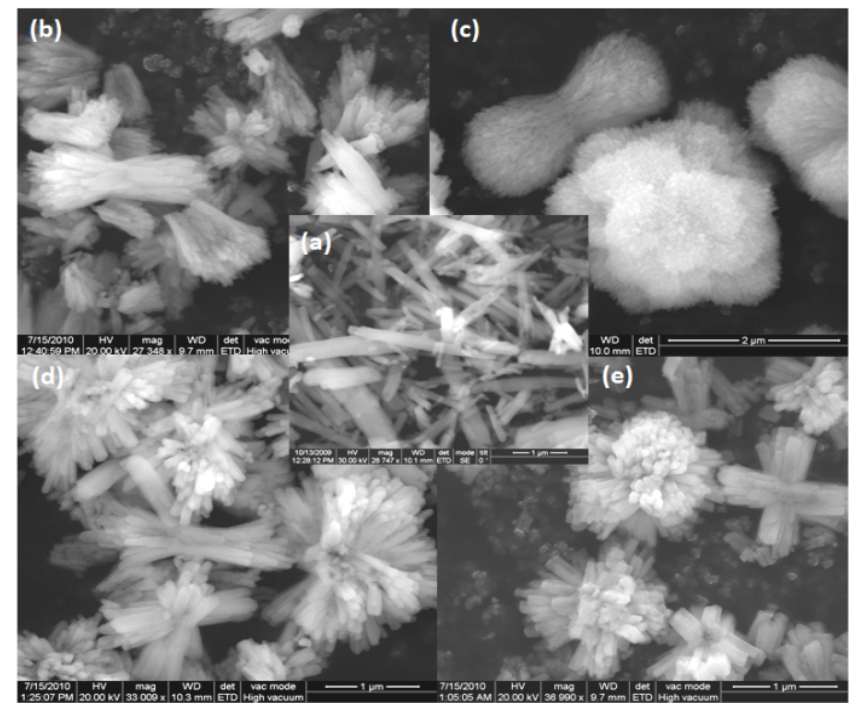

Figure 3. SEM images of $\mathrm{BaCO}_{3}$ clusters (a) rod shaped witherite (aragonite-type) crystals without gum acacia $(b, c)$ room temp reaction using 0.5 and $1.0 \% \mathrm{GA}$, and $(\mathrm{d}, \mathrm{e})$ hydrothermal $\left(90^{\circ} \mathrm{C}\right)$ reaction with 0.5 and $1.0 \%$ GA.

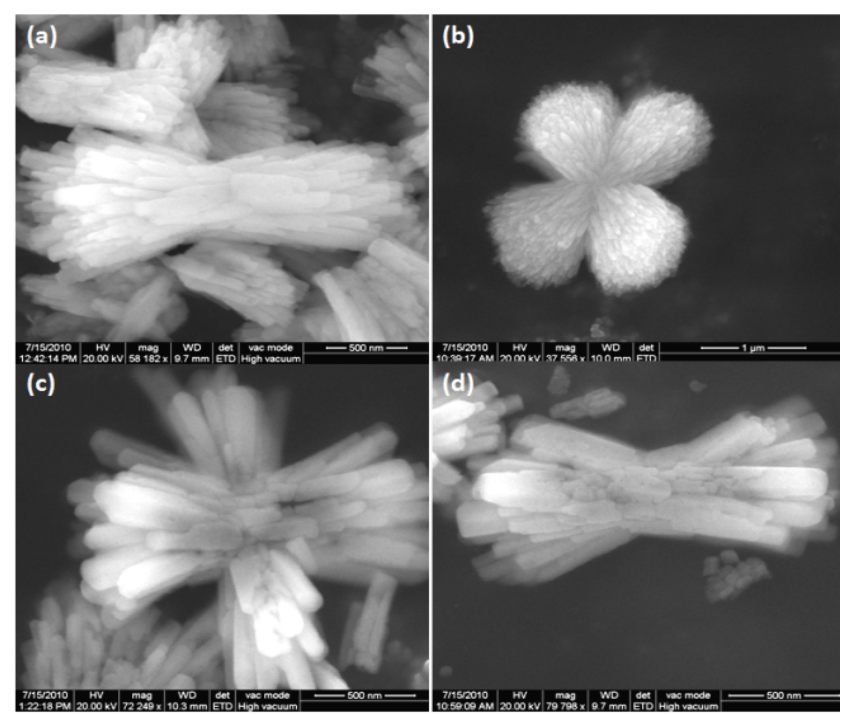

Figure 4. Enlarged SEM images of $\mathrm{BaCO}_{3}$ clusters at different reaction conditions (a) $0.5 \% \mathrm{GA}$ at room temperature, (b) $1 \% \mathrm{GA}$ at room temperature, (c) $0.5 \% \mathrm{GA}$ at hydrothermal $90^{\circ} \mathrm{C}$, and (d) $1 \%$ GA at hydrothermal $90^{\circ} \mathrm{C}$

Figure 5 shows that TEM images of $\mathrm{BaCO}_{3}$ crystals obtained using $1 \% \mathrm{GA}$ in aqueous solution (a) before and (b) 
after calcinations at $700^{\circ} \mathrm{C}$. As can be seen, the morphology of the particles obtained in the presence of GA is dumbbell, double dumbbell and flower like clusters (Figure 5a). However, after calcination at $700^{\circ} \mathrm{C}$ the structure appears to be deformed resulting in the formation of agglomerates of smaller particles of size around $20 \mathrm{~nm}$ (Figure $5 \mathrm{c}$ ). Figure 5b, $\mathrm{d}$ shows the corresponding EDAX spectrum and selected area electron diffraction (SAED) pattern of $\mathrm{BaCO}_{3}$ clusters which clearly shows number of spots arranged in circular manner and confirms the nanocrystalline nature of grown nanoparticles. The $\mathrm{BaCO}_{3}$ clusters were believed to be self assembled by the related crystalline nanoparticles in presence of appropriate additives rather than the random agglomeration. From figure 5b, d, the EDAX elemental analysis reveals that carbon content is seen more in the as-prepared $\mathrm{BaCO}_{3}$ clusters when compared to the calcined material, which can be attributed to the formation of organic-inorganic hybrid material, the organic component mainly from GA.
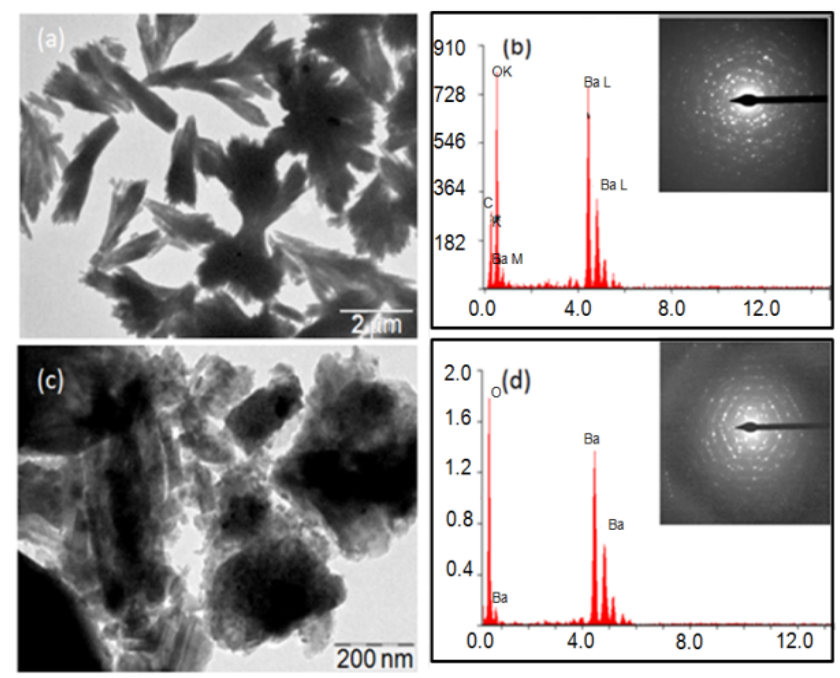

Energy (keV)

Figure 5. TEM images and EDAX (SAED inserted) of $\mathrm{BaCO}_{3}(\mathrm{a}, \mathrm{b})$ in the presence of $1 \% \mathrm{GA}$, and $(\mathrm{c}, \mathrm{d})$ calcined product at $700^{\circ} \mathrm{C}$.

\subsection{Ba-LaCO $\mathrm{B}_{3}$ System and $\mathrm{Ba}-\mathrm{TbCO}_{3}$ System}

Other than barium carbonate, mixed metal carbonates such as $\mathrm{Ba}-\mathrm{LaCO}_{3}$ and $\mathrm{Ba}-\mathrm{TbCO}_{3}$ were synthesized at room temperature using higher GA (1.0\%) concentration.

Figure $6 \mathrm{a}, \mathrm{c}$ shows the SEM images of $\mathrm{Ba}-\mathrm{LaCO}_{3}$ and $\mathrm{Ba}-\mathrm{TbCO}_{3}$ mixed metal carbonates, respectively. As can be seen, there is a clear morphological difference between $\mathrm{BaCO}_{3}$ structures synthesized with and without the addition of rare earths. $\mathrm{Ba}-\mathrm{LaCO}_{3}$ clusters are in the form of short rods whereas $\mathrm{Ba}-\mathrm{TbCO}_{3}$ appears to be dendritic clusters. It would be instructive to understand the chemical composition of the different features observed for both $\mathrm{Ba}-\mathrm{LaCO}_{3}$ and $\mathrm{Ba}-\mathrm{TbCO}_{3}$ microstructures. This is conveniently done by spot-profile EDAX. In addition to the expected $\mathrm{Ba}, \mathrm{C}$ and $\mathrm{O}$ signals, strong signals of $\mathrm{La}$ and $\mathrm{Tb}$ are seen for $\mathrm{Ba}-\mathrm{LaCO}_{3}$ and $\mathrm{Ba}-\mathrm{TbCO}_{3}$ mixed metal carbonates, respectively as shown in figure $6 \mathrm{~b}, \mathrm{~d}$.
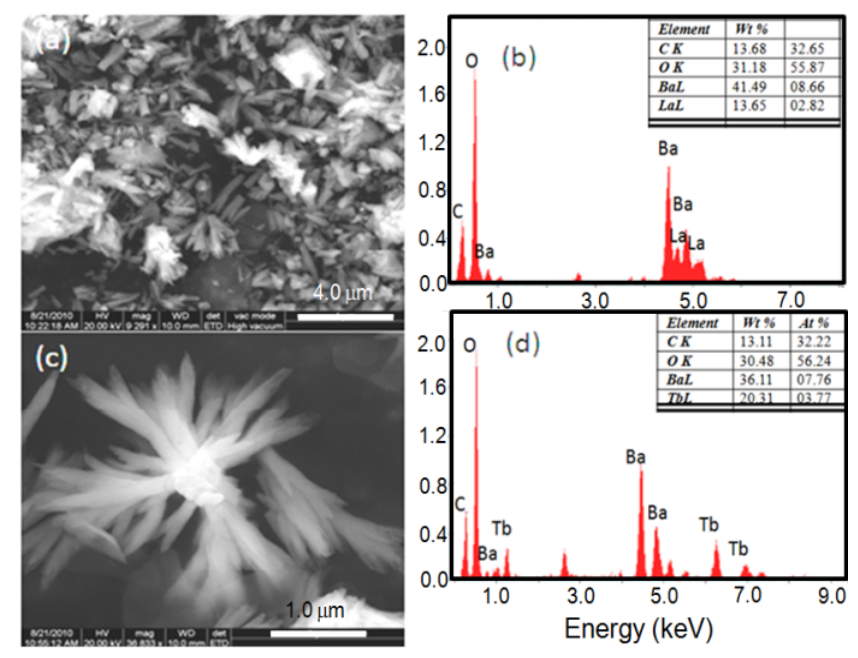

Figure 6. SEM images of mixed metal carbonates (a) Short rod like clusters of $\mathrm{Ba}-\mathrm{LaCO}_{3}$, (b) EDAX data of $\mathrm{Ba}-\mathrm{LaCO}_{3}$, (c) Dendritic shaped clusters of $\mathrm{Ba}-\mathrm{TbCO}_{3}$, and (d) $\mathrm{EDAX}$ data of $\mathrm{Ba}-\mathrm{TbCO}_{3}$.

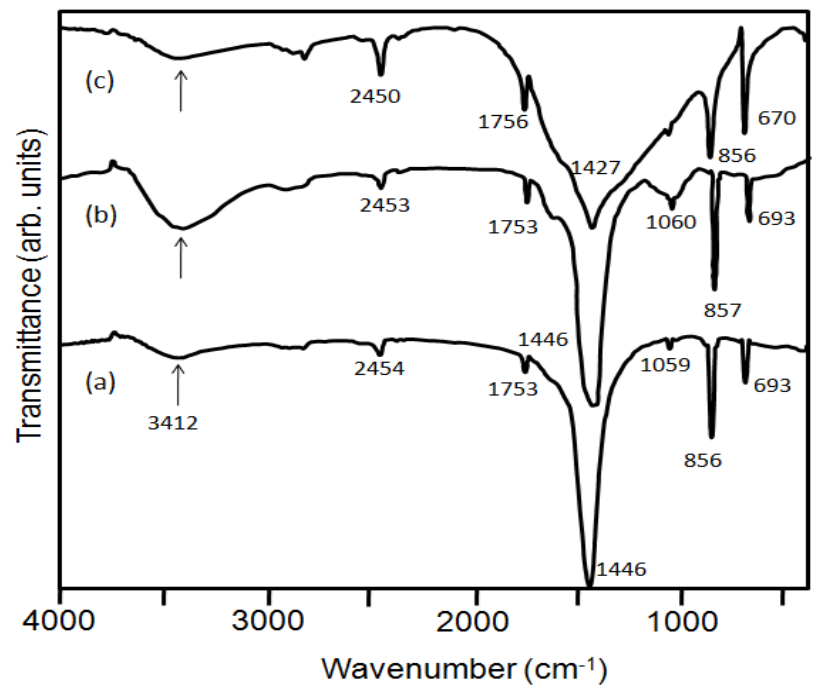

Figure 7. FT-IR spectra of $\mathrm{BaCO}_{3}$ clusters (a) nucleated in the absence of $\mathrm{GA}$, (b) nucleated in the presence of GA, and (c) calcined product at $700^{\circ} \mathrm{C}$.

\subsection{FTIR Studies}

FT-IR spectra of $\mathrm{BaCO}_{3}$ have been studied to determine the effect of GA on the microstructure of nanocrystallites. The sharp peaks at $856,693 \mathrm{~cm}^{-1}$ (Fig. 7a), 857, $693 \mathrm{~cm}^{-1}$ (Figure 7b) and $856,690 \mathrm{~cm}^{-1}$ (Figure 7c) are in-plane and out-of-plane bending of $\mathrm{CO}_{3}{ }^{2-}$. The IR bands at $1446 \mathrm{~cm}^{-1}$ (Figure 7a, b), and $1427 \mathrm{~cm}^{-1}$ (Figure 7c) correspond to the asymmetric stretching mode of $\mathrm{C}-\mathrm{O}$ bond, while the weak band at 1059 and $1060 \mathrm{~cm}^{-1}$ (Figure 7a, b) is attributed to the symmetric C-O stretching vibration. The band at $3412 \mathrm{~cm}^{-1}$ can be attributed to $\mathrm{OH}$ stretching vibration due to hydrogen bonding and or $\mathrm{N}-\mathrm{H}$ stretch of the $-\mathrm{NH}_{2}$ group from the protein present in GA (Figure 7b). In comparison with figure $8 \mathrm{~b}$ the $\mathrm{C}-\mathrm{O}$ stretching vibration peak around $1427 \mathrm{~cm}^{-1}$ in figure $7 \mathrm{c}$ shifts to lower frequency by $19 \mathrm{~cm}^{-1}\left(1446 \mathrm{~cm}^{-1}\right)$, suggesting the influence of GA on the microstructure of barium carbonate. This is probably due to the GA molecules adsorb onto the surfaces of $\mathrm{BaCO}_{3}$ nuclei and influence the 
mode of crystal growth with a little change in superstructure. Increase in the intensity of the peak at $3412 \mathrm{~cm}^{-1}$ in figure $7 \mathrm{~b}$ shows the presence of $\mathrm{GA}$ in the $\mathrm{BaCO}_{3}$ crystals resulting in the formation of inorganic-organic hybrid material.

\subsection{TGA-Mass studies}

Thermogravimetric analysis coupled to mass helps us to understand the decomposition steps more precisely as we can know the evolved gas fragments as a function of temperature or time. As representative systems, the TG/DTG-MS thermograms of pure $\mathrm{GA}, \mathrm{BaCO}_{3}$ synthesized without $\mathrm{GA}$, as synthesized $\mathrm{BaCO}_{3}$ using $\mathrm{GA}$ and $\mathrm{BaCO}_{3}$ with $\mathrm{GA}$ calcined at $700^{\circ} \mathrm{C}$ are shown (Figure $8 \mathrm{a}-\mathrm{d}$ ).

TGA-MS thermogram of pure GA (Figure 8a) shows a major decomposition step (64.5\% wt. loss) in the temperature range $260-400^{\circ} \mathrm{C}$ and it is during this step the evolution of the gas with mass fragment 44 a.m.u characteristic of $\mathrm{CO}_{2}$ from the decomposition of - $\mathrm{COOH}$ functional groups in $\mathrm{GA}$ is observed. TGA profile of $\mathrm{BaCO}_{3}$ structures synthesized without gum acacia (Figure 8b) show a single step decomposition with the onset at $850^{\circ} \mathrm{C}$. The mass fragment 44 a.m.u observed in this range clearly suggests that the $\mathrm{BaCO}_{3}$ nanocrystallites decompose into $\mathrm{BaO}$ and $\mathrm{CO}_{2}$ in this temperature range. Further, $\mathrm{BaCO}_{3}$ nanocrystallites synthesized using GA (Figure 8c) showed three step decomposition pattern. The first two steps in the temperature range are due to the decomposition of the GA component in the inorganic and organic hybrid material, and the third step with onset of decomposition at $920^{\circ} \mathrm{C}$ can be attributed mainly due to the decomposition of $\mathrm{BaCO}_{3}$ nanocrystallites. The evolution of $\mathrm{CO}_{2}$ gas in the first two steps (mass fragment 44 a.m.u) can be attributed due to the decomposition of GA component in the inorganic and organic hybrid $\mathrm{BaCO}_{3}$ nanocrystallites and the percentage of mass loss was found to be 6.2. The absence of the first two decomposition steps in the calcined $\left(\right.$ at $700^{\circ} \mathrm{C}$ ) $\mathrm{BaCO}_{3}$ synthesized with gum acacia (Figure 8d) clearly suggests that the as synthesized $\mathrm{BaCO}_{3}$ nanocrystallites are having both inorganic and organic components. As can be seen from figure $8 \mathrm{c}$, the as synthesized $\mathrm{BaCO}_{3}$ nanocrystallites using GA show the temperature of maximum decomposition at $1120^{\circ} \mathrm{C}$, which is less compared to the others and this can be attributed to the size effect of nanoparticles.

Based on the above analysis, a possible growth mechanism for the formation of flower like $\mathrm{BaCO}_{3}$ clusters at air/solution interface is schematically shown in figure 9 that follows a rod-dumbbell-flower(R-D-F) progression. The exact growth mechanism of the micro clusters is not fully understood. Initially, the various functional groups in GA inhibit the crystal growth by the encapsulation of $\mathrm{Ba}^{2+}$ ions which in the presence of sodium bicarbonate forms $\mathrm{BaCO}_{3}$ nanocrystallites that act as building units stacking in parallel sequence, resulting in the formation of micro clusters. These particles are formed homogeneously in the solution and the crystallization is based on these $\mathrm{BaCO}_{3}$ clusters that are made up of nanocrystallites and are built up from individual nanocrystals and are aligned in a common crystallographic pattern.
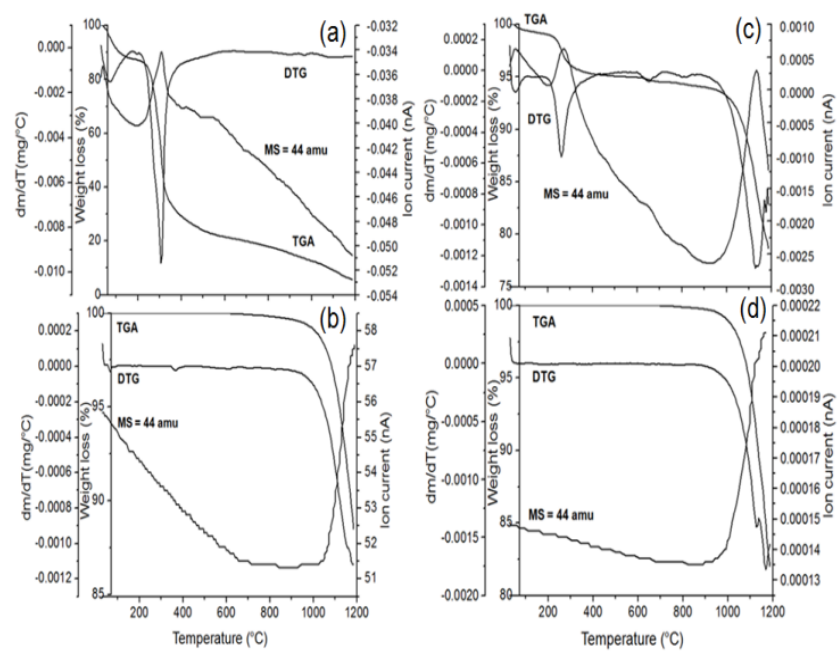

Figure 8. TGA-DTG-MS thermograms (a) pure gum acacia, (b) $\mathrm{BaCO}_{3}$ synthesized without $\mathrm{GA}$, (c) as synthesized $\mathrm{BaCO}_{3}$ using $\mathrm{GA}$, and (d) as synthesized $\mathrm{BaCO}_{3}$ with $\mathrm{GA}$ calcined at $700^{\circ} \mathrm{C}$.

The first stage is the nucleation process that is the initial reaction between $\mathrm{Ba}^{2+}$ and $\mathrm{CO}_{3}{ }^{2-}$ ions leading to the formation of $\mathrm{BaCO}_{3}$ nuclei. In the second stage, due to the presence of crystal growth modifying functional groups $(-\mathrm{OH}$, $-\mathrm{COOH},-\mathrm{NH}_{2}$ ) in $\mathrm{GA}$, formation of $\mathrm{BaCO}_{3}$ rods via orientation growth along (111) face take place as is demonstrated by XRD studies. The third stage involves the self assembly of rods via hydrogen bonding (aggregation) leading to the formation of flowers, thus illustrating the development of $\mathrm{BaCO}_{3}$ micro clusters and inferring role of GA as crystal growth modifier. In the present work, it is believed that the functional groups in GA control the formation of $\mathrm{BaCO}_{3}$ clusters by adsorbing onto certain facets of $\mathrm{BaCO}_{3}$ crystals. However, it has to be pointed out that the exact growth mechanism is still unknown, although some explanation was given in the literature based on the role of intrinsic electric fields which direct the growth of dipole crystals[45-47].

From the above morphological evolvement, we could clearly see the important role of functional group moieties in GA which bind to $\mathrm{Ba}^{2+}$ ion under varied conditions during the crystal formation and growth process. On the basis of SEM observations, the crystal growth mechanism for the generation of $\mathrm{BaCO}_{3}$ clusters at all major stages is illustrated in figure 9. The growth process of the rod-dumbbellflower(R-D-F) progression was carefully followed by concentration dependent experiments. SEM images of the products with different concentrations showed an obvious growth process from rods to dumbbell to flower with GA.

The selective absorption of functional moieties on the different planes of $\mathrm{BaCO}_{3}$ clusters resulted in varied growth rate along various planes and account for the anisotropic growth to form a flower shaped $\mathrm{BaCO}_{3}$ cluster at $1 \% \mathrm{GA}$. When the concentration of GA is decreased to $0.5 \%$ such absorption becomes weak so the aggregation process is low which results in the formation of dumbbell like structures. Furthermore, as observed without GA such absorption disappears resulting in the formation of micro rods. Hence we conclude that the change in the morphology of $\mathrm{BaCO}_{3}$ is 
influenced by the concentration of GA.

Introduction of a second bivalent metal ion $\left(\mathrm{La}^{2+} / \mathrm{Tb}^{2+}\right)$ to the crystallization medium shows interesting morphology different from that of flower - shaped barium carbonate. In the case of $\mathrm{Ba}-\mathrm{LaCO}_{3}$ individual short rods are formed whereas in $\mathrm{Ba}-\mathrm{TbCO}_{3}$ the individual rods attached to each other forming dendritic structures. Since the ionic radius of $\mathrm{La}^{2+}(1.09)$ and $\mathrm{Tb}^{2+}(1.22)$ is close to that of $\mathrm{Ba}^{2+}(1.14)$, it is conceivable that the $\mathrm{La}$ and $\mathrm{Tb}$ atoms replace $\mathrm{Ba}^{2+}$ ions or vice versa in the crystal lattice[48]. If the ionic radius of the competing ion is close to that of barium or greater than that of barium the competing ion will probably go to the kink sites[49]. In our control experiments carried out in the additive, rod shaped crystals were observed (Figure 3a). Hence mixed metal ions play a significant role in the formation of clusters in biomineralisation research. However, further studies are needed to identify various existing pathways. Even though, we used a high concentration of the bivalent ions, it is interesting to see the strong incorporation of these bivalent ions in the crystal lattice of $\mathrm{BaCO}_{3}$. The use of readily available starting materials would enable one to synthesize complex inorganic structures with interesting properties.

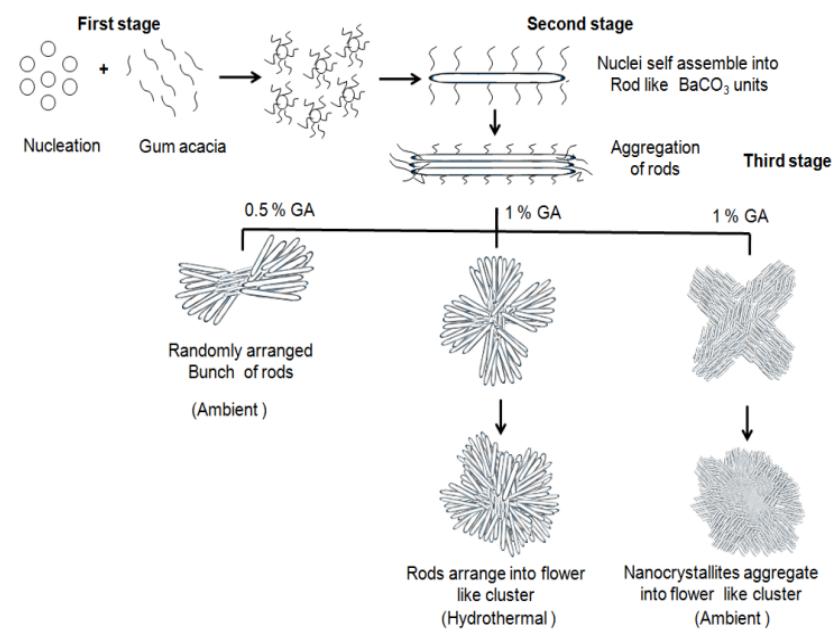

Figure 9. Schematic mechanism of $\mathrm{BaCO}_{3}$ clusters at different reaction conditions.

\section{Conclusions}

Using natural gums, a variety of crystal morphology could be produced when ambient and hydrothermal conditions were employed. In summary, we demonstrated that simple GA can be used as crystal growth modifier to template unusual complex morphologies of $\mathrm{BaCO}_{3}$ crystals. Micro clusters of barium carbonate are having different shapes such as bunch-like, dumbbell, double dumbbell and flowerlike arrangements, which are confirmed by SEM and TEM micrographs. The crystalline nature and spectral features of barium carbonate is confirmed by XRD and FT-IR spectra, respectively. TGA-MS study confirms that the as synthesized $\mathrm{BaCO}_{3}$ nanocrystallites using GA are having both inorganic and organic components resulting into the forma- tion of inorganic-organic hybrid materials. The present results demonstrate that the crystallization methods using natural gums provide a new way to realize morphological control of biomineralisation for synthesizing different superstructures of minerals or inorganic-organic hybrid materials.

\section{REFERENCES}

[1] D. B. Deoliveira, and R. A. Laursen., 1997, Control of calcite crystal morphology by a peptide designed to bind to a specific surface, J. Am. Chem. Soc. 119(44), 10627-10631

[2] T. Kato, A. Sugawara, and N. Hosoda., 2002, Calcium carbonate-organic hybrid materials" Adv. Mater. 14(12), 869-877.

[3] H. Colfen, and S. Mann., 2003, Higher-order organization by mesoscale self-assembly and transformation of hybrid nanostructures, Angew. Chem. Int. Ed. 42(21), 2350-2365

[4] S. H. Yu, and H. Colfen., 2004, Bio-inspired crystal morphogenesis by hydrophilic polymers, J. Mater. Chem. 14(14), 2124-2147.

[5] H. Colfen, and S. H. Yu., 2005, Biomimetic Mineralization/Synthesis of Mesoscale Order in Hybrid Inorganic-Organic Materials via Nanoparticle Self-Assembly, MRS Bull. 30(10), 727-735

[6] G. Falini, S. Albeck, and L. Addadi., 1996, Control of aragonite or calcite polymorphism by Mollusk shell macromolecules, Science. 271, 67-69

[7] D. D. Sawall, R. M. Villahermosa, R. A. Lipeles, and A. R. Hopkins., 2004, Interfacial polymerization of polyaniline nanofibers grafted to $\mathrm{Au}$ surfaces, Chem. Mater. 16(9), $1606-1608$

[8] S.A. Morin, F.F. Amos, and S. Jin., 2007, Biomimetic assembly of zinc oxide nanorods onto flexible polymers, J. Am. Chem. Soc. 129(45), 13776-13777

[9] T. X. Wang, A. Reinecke, and H. Colfen., 2006, In situ investigation of complex $\mathrm{BaSO}_{4}$ fiber generation in the presence of sodium polyacrylate. 2. Crystallization mechanisms, Langmuir, 22(21), 8986-8994

[10] S. Tugulu, M. Harms, M. Fricke, D. Volkmer, H. and A. Klok., 2006, Polymer brushes as ionotropic matrices for the directed fabrication of microstructured calcite thin films, Angew. Chem. Int. Ed. 45(45), 7458-7461

[11] S. Ludwigs, U. Steiner, A. N. Kulak, R. Lam, and F. C. Meldrum., 2006, Bioinspired polymer-inorganic hybrid materials, Adv. Mater. 18(17), 2270-2273

[12] M. P. Pileni, T. Gulik-Krzywicki, J. Tanori, A. Filankembo, and J. C. Dedieu., 1998, Template design of microreactors with colloidal assemblies: Control the growth of copper metal rods, Langmuir, 14(26), 7359-7363

[13] G. D. Rees, R. Evans-Gowing, S. J. Mammond, and B. H. Robinson., 1999, Formation and morphology of calcium sulfate nanoparticles and nanowires in water-in-oil microemulsions, Langmuir 15(6), 1993-2002 
[14] A. L. Briseno, S. B. Mannsfeld, M. M. Ling, S. H. Liu, J. R. Tseng, C. Reese, M. E. Roberts, Y. Yang, F. Wudl, and Z. N. Bao., 2006, Patterning organic single-crystal transistor arrays, Nature, 444, 913-917

[15] Y. H. Li, V. P. Kotzeva, and D. J. Fray., 2006, Electrochemical performance of CdS nanomaterials synthesized by microemulsion techniques, Mater Lett. 60 (21-22), 2743-2746

[16] W. J. Liu, W. D. He, and Z. C. Zhang., 2006, Fabrication of $\mathrm{CdS}$ nanorods in inverse microemulsion using HEC as a template by a convenient $\gamma$-irradiation technique, J. Cryst. Growth 290 (2), 592-596

[17] J. E. Schaefar, H. Kisker, H. Kronmuller, and R. Wurschum. 1992, Magnetic properties of nanocrystalline nickel, Nanostruct. Mater. 1(6), 523-529

[18] S. Komarneni, M. C. D. Arrigo, C. Leionelli, G. C. Pellacani, and H. Kotuku., 1998, Microwave-hydrothermal Synthesis of nanophase ferrites, J Am. Ceram. Soc. 81, 3041-3044

[19] P. P. Phule, and D. C. Grundy., 1994, Pathways for the low temperature synthesis of nano-sized crystalline barium zirconate, Mater Sci Eng B. 23(1), 29-35

[20] A. Chatterjee, D. Das, S. K. Pradhan, and D. Chakravorty., 1993, Synthesis of nanocrystalline nickel-zinc ferrite by the sol-gel method, J Magn. Magn. Mater. 127 (1-2), 214-218

[21] I. Sondi, and E. Matijevic., 2003, Homogeneous precipitation by enzyme-catalyzed reactions. 2. Strontium and barium carbonates, Chem. Mater. 15 (6), 1322-1326

[22] D. M. Sun, Q. S. Wu, and Y. P. Ding., 2006, A novel method for crystal control: synthesis and design of strontium carbonate with different morphologies by supported liquid membrane, J. Appl. Cryst. 39 (4), 544-549

[23] T. Wang, A.W. Xu, and H. Colfen., 2006, Formation of self-organized dynamic structure patterns of barium carbonate crystals in polymer-controlled crystallization, Angew. Chem. Int. Ed. 45 (27), 4451-4455

[24] S. H. Yu, H. Colfen, and M. Antonietti., 2003, Polymer-controlled morphosynthesis and mineralization of metal carbonate superstructures, J. Phys. Chem. 107 (30), 7396-7405

[25] S. H. Yu, H. Colfen, A. W. Xu, and W. Dong., 2004, Complex spherical $\mathrm{BaCO}_{3}$ superstructures self-assembled by a facile mineralization process under control of simple polyelectrolytes, Cryst. Growth and Des. 4(1), 33-37

[26] L. Chen, Y. Shen, A. Xie, J. Zhu, Z. Wu, and L. Yang., 2007, Nanosized barium carbonate particles stabilized by cetyltrimethylammonium bromide at the water/hexamethylene interface, Cryst. Res. Technol. 42 (9), 886-889

[27] K. Konno, M. Koide, and A. Kitahara., 1984, Preparation of barium carbonate particles using a W/O microemulsion, J. Chem. Soc. Jpn. 6, 815-822

[28] K. Kandori, K. Kon-no, and A. Kitahara., 1988, Preparation of $\mathrm{BaCO}_{3}$ particles in ionic w/o microemulsions, J. Disp. Sci. Technol. 9(1), 61-73

[29] L. Qi, J. Ma, H. Cheng, and Z. Zhao., 1997, Reverse micelle based formation of $\mathrm{BaCO}_{3}$ nanowires, J. Phys. Chem. B. 101(18), 3460-3463
[30] M. Dinamani, P. V. Kamath, and R. Seshadri., 2003, Electrodeposition of $\mathrm{BaCO}_{3}$ coatings on stainless steel substrates, Cryst. Growth Des. 3 (3), 417-423

[31] P. Balaz, and B. Plesingerova., 2000, Thermal propertie of mechanochemically pre-treated precursors of $\mathrm{BaTiO}_{3}$ synthesis, Journal of Thermal Analysis and Calorimetry, 59 (3) 1017-1021

[32] B. F. Allen, N. M. Faulk, S. C. Lin, R. Semiat, D. Luss, and J. T. Richardson., 1992, A continous coprecipitation process for the production of 1-2-3 precursors, AIChE Symp. Ser. 88, $76-87$

[33] J. J. Macketta., 1977, Encyclopedia of Chemical Processing and Design, Marcel Dekker, New York, 51

[34] A. Taubert, G. Glasser, and D. Palms., 2002, Kinetics and particle formation mechanism of zinc oxide particles in polymer-controlled precipitation from aqueous solution, Langmuir 18(110), 4488-4494

[35] J. Norwig, W. H. Meyer, and G. Wegner., 1998, Control of $\mathrm{ZnO}$ crystallization by a PEO- $b$-PMAA diblock copolymer, Chem. Mater. 10(2), 460-463

[36] D. K. Devi, S. V. Pratap, R. Haritha, K. S. Sivudu, P. Radhika, and B. Sreedhar., 2011, Gum acacia as a facile deducing, stabilizing, and templating agent for palladium nanoparticles, J. Appl. Polym. Sci. 121(3), 1765-1773

[37] B. Sreedhar, P. S. Reddy, and D. K. Devi., 2009, Direct one-pot reductive amination of aldehydes with nitroarenes in a domino fashion: catalysis by gum-acacia-stabilized palladium nanoparticles, J. Org. Chem. 74(22), 8806-8809

[38] H. Colfen, and M. Antonietti., 1998, Crystal design of calcium carbonate microparticles using double-hydrophilic block copolymers, Langmuir 14(3), 582-589

[39] N. A. J. M. Sommerdijk, and G. de. With, 2008, Biomimetic $\mathrm{CaCO}_{3}$ mineralization using designer molecules and interfaces, Chem. Rev. 108(11), 4499-4550

[40] H. Colfen., 2001, Double-hydrophilic block copolymers: Synthesis and application as novel surfactants and crystal growth modifiers, Macromol. Rapid Commun. 22(4), 219-252

[41] L. M. Qi, H. Colfen, M. Antonietti, M. Li, J. D. Hopwood, A. J. Ashley, and S. Mann., 2001, Formation of $\mathrm{BaSO}_{4}$ fibres with morphological complexity in aqueous polymer solutions, Chem. Eur. J. 7(16), 3526-3532

[42] L. M. Qi, H. Colfen, and M. Antonietti., 2000, Crystal design of barium sulfate using double-hydrophilic block copolymers, Angew. Chem. Int. Ed. 39(3), 604-607

[43] A. M. Belcher, X. H. Wu, R. J. Christensen, P. K. Hansma, G. D. Stuky, and D. E. Morse., 1996, Control of crystal phase switching and orientation by soluble mollusc-shell proteins, Nature 381, 56-58

[44] S. Mann, B. R. Heywood, S. Rajam, and J. D. Birchall., 1988, Controlled crystallization of $\mathrm{CaCO}_{3}$ under stearic acid monolayers, Nature 334, 692-694

[45] H. Colfen, and L. Qi., 2002, The mechanism of the morphogenesis of $\mathrm{CaCO}_{3}$ in the presence of poly(ethylene glycol)- $b$ -poly(methacrylic acid), Prog. Colloid Polym. Sci. 117, 200-203 
[46] R. Kniep, and S. Busch., 1996, Biomimetic growth and self-assembly of fluorapatite aggregates by diffusion into denatured collagen matrices, Angew. Chem., Int. Ed. Engl. $35(22), 2624-2626$

[47] S. Busch, H. Dolhaine, A. DuChesne, S. Heinz, O. Hochrein, F. Laeri, O. Podebrad, U. Vietze, T. Weiland, and R. Kniep., 1999, Biomimetic morphogenesis of fluorapatite-gelatin composites: Fractal growth, the question of intrinsic electric fields, core/shell assemblies, hollow spheres and reorganiza- tion of denatured collagen., Eur. J. Inorg. Chem. 1999(10), $1643-1653$

[48] S. Sindhu, S. Jegadesan, R. A. Edward Leong, and S. Valiyaveettil., 2006, Morphosynthesis of mixed metal carbonates using micellar aggregation., Crystal Growth \& Design. 6(6), 1537-1541

[49] N. H. De Leeuw, 2002, Molecular dynamics simulations of the growth inhibiting effect of $\mathrm{Fe}^{2+}, \mathrm{Mg}^{2+}, \mathrm{Cd}^{2+}$ and $\mathrm{Sr}^{2+}$ on calcite crystal growth., J. Phys. Chem. B. 106(20), 5241-5249 